\title{
РЕЦЕНЗИИ
}

\section{Revolutionary Russia in American Eyes}

\author{
D. S. Foglesong
}

For citation: Foglesong D.S. Revolutionary Russia in American Eyes. Vestnik of Saint Petersburg University. History, 2018, vol.63, issue 3, pp. 957-971. https://doi.org/10.21638/11701/spbu02.2018.319

To mark the centenary of the Russian revolutions of 1917, American publishers released several new histories in 2017, including a massive study by the distinguished scholar Laura Engelstein and a lengthy account by the prolific author Sean McMeekin. This article develops a critical perspective on the books by Engelstein and McMeekin by setting them in the context of other scholarship and by contrasting them to the views presented by American witnesses of the Russian revolutions. The review essay focuses primarily on three major issues: the nature of the February Revolution; the relationship between the Bolsheviks and Germany; and foreign intervention in the Russian Civil War. It argues that there are serious problems in McMeekin's and Engelstein's treatments of those issues. Their presentation of the revolution of February 1917 as a political event rather than a social transformation, McMeekin's depiction of the Bolsheviks as pawns of Imperial Germany, and both authors' downplaying of American interventions in Russia ignore the views of Americans who were in Petrograd at the time, and disregard much important scholarship published since the 1960s. By drawing on those eyewitness accounts and historical studies, this article reminds scholars of how the February Revolution both reflected and stimulated a profound change in many Russians' ways of thinking, how Americans as well as Germans funded propaganda campaigns in Russia in 1917, and how the United States intervened in the Russian civil war in several other ways, with the ultimate objective of restoring a democratic or at least a non-Bolshevik government.

Keywords: revolution, Russia, Americans, United States, propaganda, intervention, Wilson.

\section{Революционная Россия глазами американцев}

\section{Д. С. Фоглсон}

Для цитирования: Foglesong D. S. Revolutionary Russia in American Eyes // Вестник Санкт-Петербургского университета. История. 2018. Т. 63. Вып. 3. С. 957-971. https://doi.org/10.21638/11701/ spbu02.2018.319

David S. Foglesong - PhD, Professor of History, Rutgers University, 16, Seminary pl., New Brunswick (N)), 08901-1108, USA; dsfogle@history.rutgers.edu

Дэвид С. Фоглсон - PhD, проф., Университет Ратгерс, США, 08901-1108, Нью-Джерси, НьюБрансуик, пл. Семинари, 16; dsfogle@history.rutgers.edu.

(C) Санкт-Петербургский государственный университет, 2018 
В ознаменование столетия русских революций 1917 г. в 2017 г. американские издательства выпустили несколько новых книг. Среди них - фундаментальный труд известного историка Лоры Энгельштейн «Россия в огне: война, революция, гражданская война, 1914-1921» и многостраничная работа плодовитого ученого Шона Мак-Микина «Русская революция: новая история». В этой статье представлен критический обзор исследований Энгельштейн и Мак-Микина. Автор сравнивает их работы с работами других историков и документальными свидетельствами американцев, ставших очевидцами русских революций, - журналистки Бесси Битти, сотрудников американского посольства в Петрограде и т.д. В статье рассмотрены три ключевых вопроса: природа Февральской революции, отношения между большевиками и властями Германии, а также иностранная интервенция в годы Гражданской войны в России. Автор утверждает, что в интерпретации этих проблем Мак-Микин и Энгельштейн допустили серьезные ошибки. В их работах Февральская революция предстает не социальной трансформацией, а политическим событием; у Мак-Микина большевики изображаются пешками имперской Германии. Оба автора преуменьшают роль американской интервенции в России, игнорируя и мнение американцев, находившихся на время рассматриваемых событий в Петрограде, и значительную часть работ американских историков более позднего периода, публиковавшихся начиная 1960-х годов. Приводя соответствующие свидетельства очевидцев и основываясь на трудах видных историков, автор статьи обращает особое внимание на то, что Февральская революция сильно повлияла на мировоззрение значительного числа русских людей, что американцы наряду с немцами спонсировали пропагандистские кампании в России в 1917 г. и что вмешательство американцев в ход Гражданской войны было разноплановым и имело своей целью восстановление демократического или, по крайней мере, небольшевистского правительства.

Ключевые слова: революция, Россия, американцы, Соединенные Штаты, пропаганда, интервенция, Вильсон.

\section{Introduction}

One hundred years after the Russian revolutions of 1917, how well do American historians understand the events that did so much to shape the course of world history for most of the twentieth century? The recent publication of ambitious books by two prominent historians offers an occasion to consider the status of contemporary American scholarship about revolutionary Russia.

Sean McMeekin, a native of Idaho, earned his PhD at the University of California at Berkeley, where he worked most closely with the famous historian Martin Malia. Now a professor at Bard College in New York, McMeekin is the author of seven books, including The Russian Origins of the First World War (2001), which shifted the focus from Germany's grab for world power to how dishonest Russian diplomats bamboozled Britain into risking its empire "to satisfy Russian imperial ambitions"1. McMeekin's new 400-page book, The Russian Revolution, has been widely reviewed in major newspapers as well as scholarly journals. One reviewer praised it as "a superb and eye-opening account" that provides "a reliable guide to a complex story." Another reviewer called it "well-written, with new details from archival research used for vivid description of key events"2.

${ }^{1}$ McMeekin S. The Russian Origins of the First World War. Cambridge, 2001. P. 1-3, 238-242.

2 Hartle T. 'The Russian Revolution' is a superb account of this seminal event // Christian Science Monitor. 2017. June 1; Feifer G. A New History Recalibrates the Villains of the Russian Revolution // New York Times. 2017. June 6. 
Laura Engelstein, the Henry S. McNeil Professor Emerita of Russian History at Yale University, earlier taught at Cornell University and Princeton University. In a long and outstanding career, she published several major studies, beginning with Moscow, 1905: Working-Class Organization and Political Conflict (1982). In that excellent book, which appeared as many Western historians of Russia were shifting their attention from political to social history, Engelstein illuminated the development of radical consciousness and activism by workers in Moscow and revealed strained relations between different classes that foreshadowed more severe social polarization later ${ }^{3}$. Her new 800-page history, Russia in Flames, represents a culmination of decades of research and pioneering scholarship. It has been praised by reviewers. One hailed it as a "prodigiously researched and unimpeachably balanced chronicle of Russia through the bloody first decades of the $20^{\text {th }}$ century"4. Another senior historian hailed it as a "magnificent volume" .

Both McMeekin and Engelstein present their books as offering novel and original interpretations of the Russian revolutions. McMeekin's subtitle asserts that his book is "A New History", and he repeatedly boasts about presenting "new evidence" from archives in Russia ${ }^{6}$. Engelstein less flamboyantly sets her study in a twenty-first century perspective and emphasizes how it builds upon post-Soviet archival research ${ }^{7}$.

However, what is most striking about these two major books is how much the authors revert to old-fashioned views of the Russian revolutions and civil war. Like one of the earliest historians of revolutionary Russia, Sir Bernard Pares, Engelstein and especially McMeekin emphasize the personalities and agency of leading figures, from Tsar Nicholas II and Empress Alexandra to Alexander Kerensky and Vladimir Lenin ${ }^{8}$. McMeekin and Engelstein also revive the "stabilization thesis" embraced by an earlier generation of historians. Like George F. Kennan, they argue that the Russian Revolution was not inevitable; that in the years before 1914 tsarist Russia was on a promising path, with rapid economic growth and a vibrant civil society; and that if Russia had avoided being drawn into the European War, it would have continued on a hopeful course of modernization". "Had it not been for the trauma of the Great War", Engelstein writes, "Russia might conceivably have developed some form of capitalist society, with a truly representative and empowered political system"10. McMeekin goes further: the prewar period had been "an era of great economic and social progress", the war brought a "boom", and even after two and a half years of fighting "there was nothing inevitable about the collapse of the regime in 1917". Morale in the Russian Army was "superlative" and "gung-ho" at the beginning of the year,

${ }^{3}$ While praising Moscow, 1905 as a fine study, reviewers criticized Engelstein for overstating workers' interest in participating in a democratic political process and overlooking the depth of the autocracy's resistance to political compromise - points relevant to consideration of her new book, as well. See: Smith S. A. Moscow Workers and the Revolutions of 1905 and 1917 // Soviet Studies. 1984. Vol.XXXVI, N 2. P. 282-289; Langer L. N. Russia in Revolution // Studies in Comparative Communism. 1984. Vol. XVII, N 2. P. 137-149.

4 Smith D. Flames and Famine // Los Angeles Review of Books. 2017. November 16.

${ }^{5}$ Orlovsky D. The Russian Revolution at 100: Four Voices // Slavic Review. 2017. Vol.76, N 3. P. 768.

${ }^{6}$ McMeekin S. The Russian Revolution: A New History. New York, 2017. P. 133, 135.

7 Engelstein L. Russia in Flames: War, Revolution, Civil War, 1914-1921. New York, 2017. P.XXIIXXIII.

${ }^{8}$ See: Pares B. Rasputin and the Empress: Authors of the Russian Collapse // The Russian Revolution and Bolshevik Victory / eds R. Suny, A. Adams. Lexington (MA), 1990. P. 16-25.

9 Kennan G.F. The Fateful Alliance: France, Russia and the Coming of the First World War. New York, 1984.

10 Engelstein L. Russia in Flames... P.XV. 
he claims. If the weather had not turned unusually warm in late February, massive crowds would not have ventured into the streets of Petrograd, and the Russian political landscape would not have been transformed. If the weak-willed Tsar's train had not been re-routed at a crucial moment, his wife "would have put steel into him", and disturbances in the capital easily would have been suppressed. Thus, instead of being deeply rooted in class conflict and the long-term undermining of the authority of the autocracy, the Russian Revolution was a result of accidents and chance events ${ }^{11}$.

This article will not focus on responding to those old-fangled views. For a more convincing account of the disintegration of tsarist authority in the Army, readers can consult the definitive work of Allan Wildman ${ }^{12}$. And for a comprehensive explanation of the deep roots of the revolutions of 1917 in the stubbornly reactionary nature of the tsarist regime and fundamental social conflicts, readers can turn to a weighty book by Orlando Figes ${ }^{13}$. Instead, this essay will concentrate on three other questions to which McMeekin and Engelstein give old-style answers: 1) whether the February Revolution is best understood as a political or a social revolution; 2) whether German funding of the Bolsheviks decisively determined the course of events between the February Revolution and the widening of the civil war in the summer of 1918; and 3) why and how the United States intervened in the Russian civil war.

\section{The February Revolution}

Both McMeekin and Engelstein present the February Revolution against the Romanov autocracy primarily as a political revolution engineered by elites. Although McMeekin acknowledges that some important developments in Petrograd, including a general strike by factory workers, were spontaneous, he argues that it was "Russia's liberals" who began the revolution with "their dangerous palace plots." Actually, two key plotters in McMeekin's account - Mikhail Rodzianko and Aleksandr Guchkov --were conservatives, but McMeekin directs his fire more at liberals who "unleashed political chaos and gravely

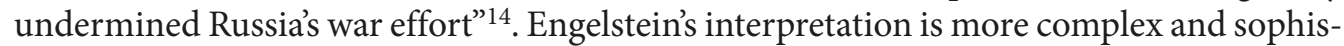
ticated. She recognizes at the outset that "in February, Russian Imperial society, from top to bottom, rose up against the autocratic regime". Yet she repeatedly gives primacy to elites and downplays the role of the masses. "The monarchy was ousted by the representatives of privileged society, backed by the fury of soldiers, peasants, and workers," she argues. "The men who took matters into their own hands and turned against the monarchy", she underscores, "were the notables of the State Duma," who formed a provisional government. The fundamental impulse of the revolution that began in February, she concludes, "was the desire for democratic political participation". Although Engelstein, unlike McMeekin, cites important social history studies of revolutionary Russia published since the 1970s and devotes a chapter to "Politics from Below," she insists that what happened in 1917 was a "political revolution" and argues that the events of February and October "can be de-

11 McMeekin S. The Russian Revolution: a New History... P.XVII, XIV, 110, 95, 103, 115.

12 Wildman A.K.: 1) The End of the Russian Imperial Army: the Old Army and the Soldiers Revolt (March-April 1917). Vol. I. Princeton, 1980; 2) The End of the Russian Imperial Army: the Road to Soviet Power and Peace. Vol. II. Princeton, 1987.

${ }_{13}^{13}$ Figes O. A People's Tragedy: A History of the Russian Revolution. New York, 1997.

14 McMeekin S. The Russian Revolution: a New History... P. 97, 344. 
scribed as coups". Thus, instead of building upon and advancing beyond the scholarship of the last forty years that has broadened our understanding of the Russian revolutions, Engelstein and McMeekin revert to an older style of political history ${ }^{15}$.

Although neither Engelstein nor McMeekin fully recognizes it, in the first months of 1917 something fundamental changed in the ways ordinary Russians thought and felt, which led them to take direct action - not to back the maneuvers of representatives of privileged society but to fulfill their own dreams and desires. Even Americans in Petrograd who were partly blinded by their own ideologies and prejudices caught glimpses of a new and pervasive spirit, a spirit of insubordination. On March 12, James Houghteling, a special attache to the US Embassy, "watched officers vainly trying to make a battalion fall in". Even when an officer drew his pistol and pointed it at the soldiers, many of them shrugged their shoulders and walked away. Houghteling also heard about the new spirit when he listened four days later to a story of an American factory owner whose workers suddenly refused to labor full time. After the owner fired them, the workers "defied him and would not leave the building" 16 . Joshua Butler Wright, the counselor of the US embassy, who also felt the "menace" of the "impossible" demands of workers, encountered the new spirit most immediately later in the spring, when his servants impudently and obstinately refused to leave after he dismissed them ${ }^{17}$.

More sympathetic Americans saw that the passions and ideas that moved ordinary Russians to act were not orchestrated or instigated by elites. Bessie Beatty, a journalist from California who arrived in Petrograd early in June 1917, understood only a few Russian words then, yet she quickly sensed that the vital energies of the revolution were neither controlled by elites nor limited to yearnings for political democracy. The most important transformation had not been the passing of formal political authority from the Tsar to a group of Duma politicians but a basic change in consciousness manifested in different ways. The key word that people of different classes across the empire used to convey the meaning of the revolution was "freedom" (svoboda), though that entailed different things to different people. "Each man translated revolution into the terms of his own life", Beatty observed. A conservative intellectual with whom Beatty dined defined freedom in terms of civil liberties: "freedom of speech, freedom of press, freedom of assembly, inviolability of person". A peasant from southern Russia proudly explained that freedom meant that peasants would finally have land that was rightfully theirs. A worker from the Putiloff factory declared that freedom meant that "the men who use the tools shall control them, the fruits of labour shall belong to labour" [sic]. A soldier who traveled from the front to attend a meeting of the Soviet of Workers' and Soldiers' Deputies defined freedom as peace, peace that would allow soldiers to go back to their farms and factories. For women, as well as for men, the revolution brought a new consciousness of their humanity and their dignity ${ }^{18}$. (Political cartoonists in the United States often tried to convey their sense that a new consciousness had arisen in the minds of common Russians with images of a worker or peasant breaking the chains that had bound him - see fig. 1 for an example.)

${ }^{15}$ Engelstein L. Russia in Flames... P.xiii, xvi, 631, 217. - In turning away from social history and back to political history, Engelstein and especially McMeekin follow in the footsteps of Richard Pipes: Pipes R. The Russian Revolution, 1899-1919. New York, 1990.

${ }^{16}$ Houghteling J. A Diary of the Russian Revolution. New York, 1918. P. 64, 170.

17 Joshua Butler Wright Diary // Mudd Library, Princeton University, entry for May 31, 1917.

18 Beatty B. The Red Heart of Russia. New York, 1918. P. 11-12. 


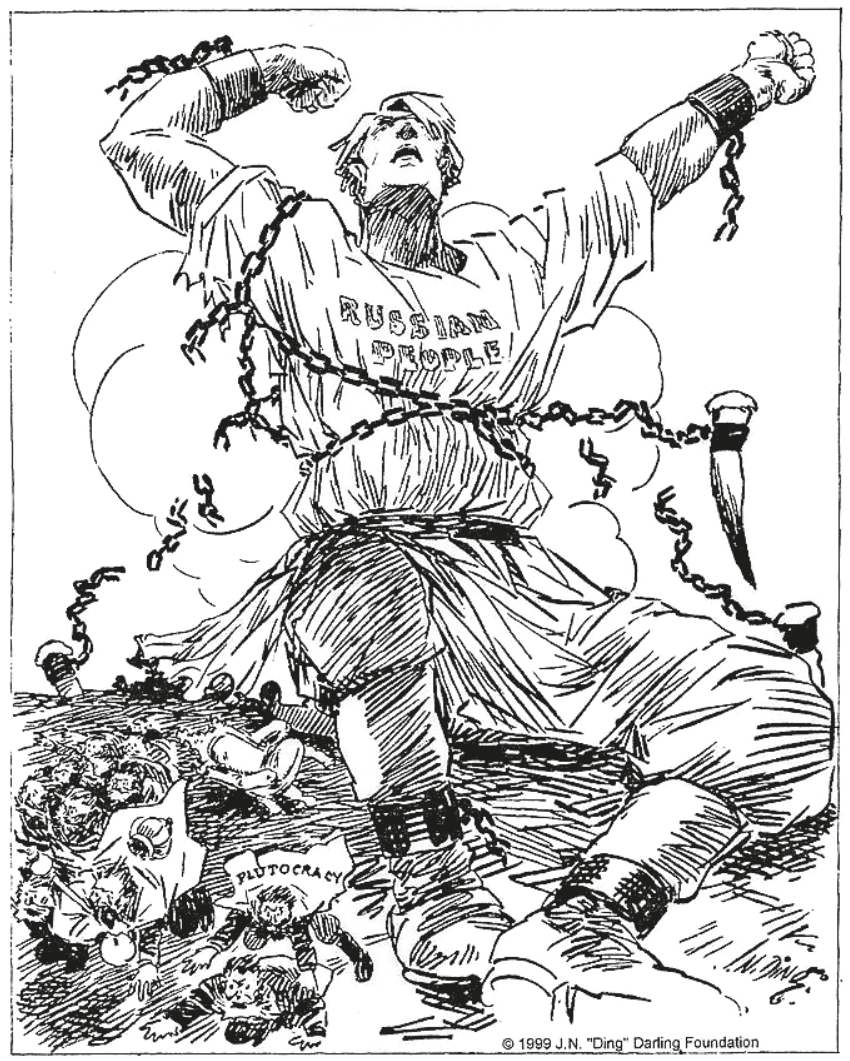

Fig. 1. The awakening of the giant (syndicated cartoon published in the "New York Herald Tribune" and other newspapers, March 16, 1917)

In contrast to McMeekin and Engelstein, Mark Steinberg, a professor at the University of Illinois, shows in a more compact history of the Russian Revolution, also published in 2017, that the February Revolution centered not on the intrigues of political and military elites but on a radical change in the hearts and minds of the Russian people. Already in January 1917 secret police agents in Petrograd reported a rising "wave of animosity against those in authority in wide circles of the population". That animosity and a growing refusal to be ruled as they had been ruled before inspired the strikes, street demonstrations, and rejections of orders that shook and toppled the autocracy. As a liberal army officer explained to his family in mid-March, Russia's rank-and-file soldiers and common people believed that "what has taken place was not a political but a social revolution". Like Beatty, Steinberg notes that with the fall of the monarchy "freedom" became the preeminent word used to express the new, widely shared ideas and emotions. Liberal feminists, soldiers, workers, and peasants interpreted "freedom" in different ways, but they agreed that the essential meaning of the revolution was not the transfer of power from Romanov royalty to bourgeois politicians but a profound change in social relations and individual attitudes ${ }^{19}$.

19 Steinberg M.D. The Russian Revolution, 1905-1921. New York, 2017. P. 69, 73-76, 14. 
For Engelstein the key concept is not "freedom" but "democracy". "From the beginning," she writes in her introduction, "the revolution held out the possibility of a democratic outcome, a potential dramatized by the remarkable turnout for elections to the empire-wide Constituent Assembly in November 1917". Moreover, she argues that at its core the revolution was "a political contest in which the ideal of democracy" resonated at all levels of society and was ultimately betrayed by the Bolshevik seizure of power. Although she later recognizes that the word demokratiia had more social and class connotations than political meaning to many Russians, in general she approaches "democracy" in a conventional American way as a political process centered on voting and representation ${ }^{20}$.

Russia in Flames thus echoes the views of US leaders in 1917. On March 18, 1917, the US Ambassador in Petrograd, David Francis, rapturously exclaimed to the State Department that the revolution in Russia was "the practical realization of that principle of government which we have championed and advocated, I mean consent by the governed". Other formal and informal advisors to the US government asserted in March that the revolution was a political, not a social revolution, and that it represented a triumph of the kind of "democracy" that President Woodrow Wilson had extolled in his speeches. Influenced by such counsel, Wilson declared in an address to Congress on April 2 that Russia was "always in fact democratic at heart", and that the "wonderful" revolution there made it possible for the United States, in entering the war against autocratic Germany, to embark on a crusade to make the world "safe for democracy" 21.

Engelstein therefore comes close to reproducing the views that misguided American responses to the revolutions of 1917 by leading US officials to overestimate popular support for the provisional government and to disregard how the aspirations of many Russians diverged from American ideals and interests.

\section{The German-Bolshevik Conspiracy}

While both Engelstein and McMeekin focus on political events more than social developments, McMeekin differs from Engelstein in his emphasis on conspiracies. He repeatedly points out, for example, that many of the key plotters against Nicholas II (including Guchkov, Kerensky, and Nikolai Nekrasov) were Masons, though he never fully elucidates the significance of that fact ${ }^{22}$. McMeekin develops a much more strident argument that German financial support for the Bolsheviks was crucial to the expansion of Bolshevik propaganda, the demoralization of Russian armed forces in 1917, and the preservation of Bolshevik power as the civil war developed in 1918. "Lenin would have had little impact on the political scene had he not been furnished with German funds to propagandize the Russian army", according to McMeekin. "Fueled by German subsidies", he writes, "Lenin succeeded in breaking the Russian Imperial Army in 1917". Then, in the summer of 1918, as the Soviet regime faced threats from anti-Bolshevik revolts in the north and a Czechoslovakian Legion advancing from western Siberia, "Lenin's beleaguered government" was saved by Latvian troops "whose salaries were subsidized by the German Embassy"23.

${ }^{20}$ Engelstein L. Russia in Flames... P. xiii, xv, 631.

${ }^{21}$ Foglesong D. S. America's Secret War Against Bolshevism: U.S. Intervention in the Russian Civil War, 1917-1920. Chapel Hill, 1995. P. 49-51.

22 McMeekin S. The Russian Revolution: a New History... P. 71-72, 86, 146, 178, 199.

${ }^{23}$ Ibid. P.xv; xvi; 257. 
McMeekin's breathless writing fosters the impression that Lenin was a German agent: he was a "card" the Germans played; he worked as the Germans wished; and the top German general Erich Ludendorff sought "to keep Lenin on a short leash". Historians who provided endorsements for the back cover of McMeekin's book highlighted this theme. "The full, shocking extent to which Lenin was a German operative now becomes clear", writes Niall Ferguson. The Bolshevik victory was "an act of treason engineered by a German army that had stuffed a billion dollars in Lenin's pockets", adds Geoffrey Wawro ${ }^{24}$.

At the time of the Russian revolutions and civil war, Americans keenly understood the potential importance of charges about German funding of the Bolsheviks for delegitimizing the Soviet regime and justifying foreign intervention. U.S. officials were so eager to promote the accusation that they purchased forged documents and then published them as a Committee on Public Information pamphlet, The German-Bolshevik Conspiracy, weeks after U.S. troops landed at Archangel and Vladivostok in 1918. In a thorough and careful analysis fifty years later (not listed in McMeekin's bibliography), George F. Kennan demonstrated that two historians whom the U.S. government used to authenticate the documents had lent their prestige to forgeries ${ }^{25}$. Although that precedent should encourage historians to be cautious in how they approach German-Bolshevik relations, the comments by McMeekin, Ferguson, and Wawro indicate that a zealous desire to discredit the Bolshevik revolution is still very much alive, a century later.

McMeekin claims that his account of German-Bolshevik ties is based on new evidence from the Communist Party Archives in Moscow. Yet he actually relies primarily on a collection of documents from the German Foreign Ministry published in 1958 and a German scholarly study from 1966 - important and valuable sources, but hardly new ${ }^{26}$.

As German documents showed more than fifty years ago, Germany expended approximately 30 million marks for antiwar propaganda in Russia in 1917. Since the exchange rate between the German mark and the US dollar in 1917 was between 5:1 and 6:1, Germany spent roughly $\$ 5$ million to $\$ 6$ million to try to push Russia out of the war. However, the United States spent much more money to try to keep Russia in the war - a fact that neither McMeekin nor Engelstein acknowledges ${ }^{27}$.

Although President Wilson realized already in mid-April 1917 that many Russians might "find the war an intolerable evil and... desire to get out of it on any reasonable terms", he thought that "would be a serious blow to the Allies", and it would mean a severe strain for the United States, which was far from ready to send troops to support the British and French on the western front. His administration, therefore, provided an initial \$100 million credit to the provisional government to purchase war supplies in the US. Americans were well aware of the effort to use money to counter German influence in Russia, as a political cartoon published in June shows (see fig. 2). In August, when

24 Ibid. P. 127, 132, 256.

${ }^{25}$ Kennan G. F. The Sisson Documents // Journal of Modern History. 1956. Vol. 28, N 2. P. 130-154.

${ }^{26}$ McMeekin S. The Russian Revolution: a New History... P. 133-135; Germany and the Revolution in Russia, 1915-1918 / ed. by Z.Zeman. London, 1958; Baumgart W. Deutsche Ostpolitik 1918. Vienna; Munich, 1966.

${ }^{27}$ For further discussion, see: Foglesong D. S. Foreign Intervention // Critical Companion to the Russian Revolution, 1914-1921 / eds E. Acton et al. London, 1997. P. 107-108; Russian edition: Kriticheskii slovar' Russkoi revoliutsii: 1914-1921. St. Peterburg, 2014. McMeekin, citing Baumgart, writes that Germany transferred a total of 50 million marks to the Bolsheviks. See: McMeekin S. The Russian Revolution: a New History... P. 134. 
Washington granted the provisional government an additional \$100 million credit to cover military contracts with US firms, Wilson explained that he sought to give moral as well as material support to the liberal government "against all enemies within and without". By November, the US authorized a total of $\$ 325$ million in loans and credits to support the Russian war effort, though only $\$ 188$ million had been transferred by November, when the provisional government was overthrown ${ }^{28}$.

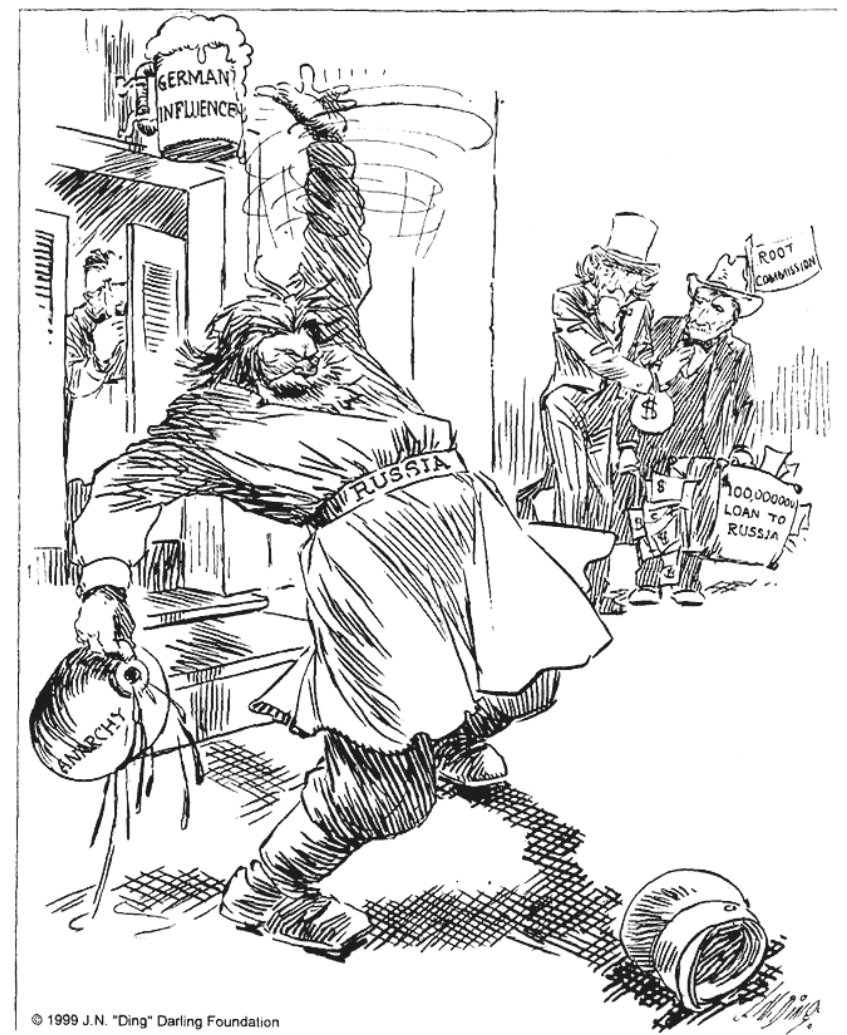

Fig. 2. Better hold that loan for awhile, Uncle (syndicated cartoon published in the "New York Herald Tribune" and other newspapers, June 13, 1917)

The United States and Britain also spent additional funds on pro-war propaganda campaigns in Russia. In May 1917 President Wilson's advisor Edward House and the chief British intelligence official in America developed plans "to offset German propaganda" which led to the dispatch of British writer Somerset Maugham to Russia, where he distributed propaganda and provided financial support to moderate socialists opposed to the Bolsheviks. In June, Arthur Bullard, a pro-war socialist confidentially backed by the

${ }^{28}$ Memorandum by John Howard Whitehouse, April 14, 1917 // The Papers of Woodrow Wilson (further - PWW) / ed. by A. S. Link. In 69 vols. Vol. 42. Princeton, 1983. P. 67; Foreign Relations of the United States, 1918, Russia. Vol.3. Washington (DC), 1932. P. 1-10; Wilson to the President of the National Council Assembly at Moscow, August 24, 1917 // PWW. Vol. 44. Washington (DC), 1984. P.38. See also: Foglesong D. S. America's Secret... P. 51, 55. 
Wilson administration, sailed to Russia, where he gave money to the Socialist Revolutionary leader E.K. Breshko-Breshkovskaia to support the publication of pro-war, pro-Ally newspapers and pamphlets. William Boyce Thompson, the head of the American Red Cross mission to Russia, gave another $\$ 1$ million from his own fortune that enabled Breshkovskaia, Kerensky's private secretary, and the Committee on Civic Education to publish many more leaflets attacking the Bolsheviks, supporting Kerensky, and praising Russia’s democratic allies in September and October 1917. As Raymond Robins, the most energetic member of the Red Cross mission, later recalled, the purpose of Thompson's contribution was to try to maintain the Russian front against Germany and keep the Bolsheviks from coming to power ${ }^{29}$.

Thus, the German financial intervention in Russia was not uniquely heinous, as McMeekin makes it seem. In addition, McMeekin's own account demonstrates that, far from being pliable tools of Germany, Lenin and the Bolsheviks stubbornly and relentlessly pursued their own goals of revolution, not only in Russia but also in Germany. Despite German demands, the Bolsheviks refused to stop distributing propaganda to German troops. After a German ambassador arrived in Moscow in 1918, the Bolsheviks even organized a parade of German prisoners of war who marched across Red Square carrying a banner reading, "German comrades, throw off your Kaiser as the Russian comrades have thrown off their tsar" 30 .

To support his stress on the role of German intrigue, McMeekin repeatedly quotes from the diary and letters of American historian Frank Golder, who recorded rumors and expressed suspicions about the activity of German agents in Petrograd ${ }^{31}$. McMeekin does not turn to the writing of other American observers who believed that Germany had disbursed money in Russia but realized that that was not what drove Bolshevik agitation. Bessie Beatty recognized that there was "something more vital than German money at work among the masses"32. She also agreed with Albert Rhys Williams, a Congregational minister and labor activist, who acknowledged that the Bolsheviks had received German money but pointed out that "Trotzky [sic] and Lenin are preaching to-day the doctrine they were preaching fifteen years ago". Along the same line, the sociologist Edward Ross, who traveled across Russia from July to December 1917, observed, "It would be strange if these men [Trotsky and Lenin], after years of intrepid devotion to a cause and of utter indifference to the threats and bribes of the tsar's ministers, should succumb to the temptation of German gold". Ross heard US officials' views about German conspiracies in Russia, but understood that Bolshevik leaders were not German agents. Imperialist and militarist Germany, he noted, was "the arch foe" of everything the Bolsheviks stood for. It was the old Russian elites whom he heard clamoring for German intervention to "restore order" and give them back their property. Thus, McMeekin's misleading suggestion that German support was the key to the Bolsheviks' seizure and maintenance of power is founded in part on a very selective use of testimony by American observers and a disregard of views

29 "Russia", memorandum by Sir William Wiseman, May 15, 1917 // Yale University. Edward M. House Papers. Box 182; "Russia", address by Raymond Robins, March 20, 1919 // State Historical Society of Wisconsin. Raymond Robins Papers. Box 43; Foglesong D. S. America's Secret... P. 108-109. In December 1917, Izvestiia seized upon revelations about the American funding to denounce Breshkovskaia as a "paid agent" of American capitalists. See: Ibid. P. 110.

${ }^{30}$ McMeekin S. The Russian Revolution: a New History... P. 256.

${ }^{31}$ Ibid., especially P. 131, 165.

32 Beatty B. The Red Heart... P. 140, 56. 
that would lead to a more complex and sophisticated perspective ${ }^{33}$. (In contrast to McMeekin, Engelstein recognizes that while Lenin's agitation for a time coincided with Germans' objectives, "he was never their tool" ${ }^{4}$.)

\section{US Intervention in the Russian Civil War}

While the books by McMeekin and Engelstein are old-fashioned in many ways, perhaps the most troubling reversion to old interpretations is their treatment of foreign interventions in the Russian civil war. During the early Cold War, American scholars such as George F. Kennan and Betty Unterberger repeatedly denied Soviet charges that US military interventions in Russia had been motivated by desires to overthrow the Bolshevik regime $^{35}$. As Christopher Lasch observed, the denial was important to escape blame for the origins of Soviet-American conflict ${ }^{36}$. However, in the 1960s "revisionist" historians such as William Appleman Williams and N. Gordon Levin demonstrated that President Woodrow Wilson and his advisers had been hostile to Bolshevism, and that the US sent military expeditions to northern Russia and eastern Siberia in the summer of 1918 not merely to guard arms stockpiles and contain Japanese expansionism (as Kennan and Unterberger had maintained) but also to assist anti-Bolshevik forces in the Russian civil war ${ }^{37}$. During the détente of the 1970s, John Lewis Gaddis, then in his post-revisionist phase, recognized that while complex circumstances related to the First World War provided the occasion for the interventions, behind the pretexts was an intense "loathing for Bolshevism"38. After the end of the Cold War, historians went further. Drawing on archival research in documents that had been classified or unused earlier, they showed that the United States had sought to support anti-Bolshevik forces in the civil war not only with the limited military interventions but also by using the Russian Embassy in Washington as a channel for arms shipments and by providing aid through the American Relief Administration and the American Red Cross. In the twenty-first century, several studies have confirmed that while the initial or ostensible purposes of the military expeditions to northern Russia and Siberia were connected to the war against Germany, the ultimate objective of the Wilson administration and the main reason why US forces remained in Russia after the end of the war against Germany was to assist the overthrow of the Soviet regime ${ }^{39}$. Not even one of the revisionist, post-revisionist, or post-Cold War studies is included in McMeekin's and Engelstein's bibliographies. Instead, they rely on an ancient collection of documents pub-

33 Ross E. A. Russia in Upheaval. New York, 1918. P. 335, 13, 334, 344.

34 Engelstein L. Russia in Flames... P. 143.

35 Kennan G. F. Soviet-American Relations, 1917-1920. In 2 vols. New York, 1956-1958; Unterberger B. America’s Siberian Expedition, 1918-1920. Durham (NC), 1956.

36 Lasch C. American Intervention in Siberia: A Reinterpretation // Political Science Quarterly. 1962. Vol. 77, N 2. P. 205-223.

37 Williams W. A. 1) American Intervention in Russia, 1917-1920 // Studies on the Left. 1963. Vol.3, N 4. P. 24-48; 2) American Intervention in Russia, 1917-1920 // Ibid. 1964. Vol. 4, N 1. P.39-57; Levin N. G. Woodrow Wilson and World Politics. New York, 1968.

38 Gaddis J.L. Russia, the Soviet Union, and the United States: An Interpretive History. $2^{\text {nd }}$ ed. New York, 1990. P.72.

${ }^{39}$ Foglesong D. S. America's Secret...; Davis D. E., Trani E. P. The First Cold War: The Legacy of Woodrow Wilson in U.S.-Soviet Relations. Columbia, 2002; Willett R. L. Russian Sideshow: America's Undeclared War, 1918-1920. Washington (DC), 2003; Richard C. J. When the United States Invaded Russia: Woodrow Wilson's Siberian Disaster. Lanham (MD), 2013. 
lished in 1936 and on the work of Cold War historians such as Kennan and Unterberger, who engaged in polemics against their Soviet counterparts ${ }^{40}$.

While McMeekin discusses German military occupation of Russian territory at length, he mentions the interventions by US and Allied forces only briefly. On August 3, 1918, he writes, a committee of delegates to the Constituent Assembly that the Bolsheviks had disbanded in February issued from their base at Samara "a formal invitation for the Allies to intervene militarily in Russia's civil war. The United States and Japan promptly signed an agreement on proposed troop deployments to Siberia. By month's end, Britain had forty thousand troops on the ground in Russia, mostly at Archangel and Murmansk. Although France had few troops to spare, Paris declared unequivocal support for intervention on August 7"41. Thus, McMeekin makes it appear that the key decisions to intervene were all precipitated by an invitation from a body that had a tenuous claim to represent the will of the Russian people. In fact, however, President Woodrow Wilson had made his first decision to intervene in December 1917, when he approved covert financial support for anti-Bolshevik forces gathering in southern Russia. Moreover, Wilson conveyed his formal approval of military expeditions to northern Russia and Siberia in an aide-memoire sent on July 17 to the Allies, who already had resolved to intervene ${ }^{42}$. Thus, McMeekin's account is deeply misleading.

In contrast to McMeekin's cursory reference to US and Allied intervention in Russia, Engelstein recognizes that "foreign powers played a key role" in the civil war and she devotes much more attention to their actions. However, her explanation of the foreign powers' motives is also misleading. The Allies' decisions, she argues, "were more pragmatic than ideological. They were not primarily concerned to destroy the Bolsheviks as a threat to domestic and world stability". Relying heavily on an essay by Unterberger, Engelstein asserts that President Wilson was even "friendly" to the Bolshevik government and steadfast in opposing intervention in Russia. We know that, Unterberger argued and Engelstein concurs, because Wilson said so in formal statements ${ }^{43}$.

This naïve interpretation ignores a series of confidential decisions and actions. Wilson rejected diplomatic relations with the Bolsheviks, whom he detested as treacherous usurpers who had 'compounded' with Germany, published the embarrassing secret treaties of the Allies, and dispersed the Constituent Assembly. Instead, the Wilson administration continued to recognize Boris Bakhmeteff, the ambassador the provisional government sent to Washington, as the representative of Russia and a symbol of American hopes for a restoration of democracy. One month after the Bolsheviks took power, Wilson gave his "entire approval" to a proposal to aid anti-Bolshevik forces around the Cossack general A. M. Kaledin. He hesitated to authorize more overt interventions because of concerns that sending military expeditions to Russia would divert forces from the western front against Germany and contradict his declared principles about non-intervention and self-determination. Finally, he agreed to dispatch troops to Archangel and Vladivostok in

${ }^{40}$ Intervention, Communism, and Civil War in Russia, April-December 1918 / ed. by J.Bunyan. Baltimore, 1936; Kennan G. F. Soviet Historiography and America's Role in the Intervention // American Historical Review. 1960. Vol.65, N 2. P.302-322; Unterberger B. Intervention Against Communism: Did the United States Try to Overthrow the Soviet Government, 1918-1920? College Station, Texas, 1987.

${ }^{41}$ McMeekin S. The Russian Revolution: a New History... P. 264.

42 Foglesong D. S. America’s Secret... P. 88, 202-204.

43 Engelstein L. Russia in Flames... P.387-388, 389-390, 403; Unterberger B. Woodrow Wilson and the Russian Revolution // Woodrow Wilson and a Revolutionary World / ed. by A. Link. Chapel Hill, 1982. 
June and July 1918. He sent the forces not merely to guard military stores and aid a supposedly beleaguered Czechoslovak Legion, as Engelstein claims, but also to make it "safe for Russian forces to come together in organized bodies" and to help "the Russian people in their endeavor to regain control of their own affairs". While Wilson carefully refrained from specifying which Russian forces he wanted to assist against whom, his advisors knew what he meant. Weeks before Wilson's final decision, Secretary of State Robert Lansing had given the president a letter from George Kennan (the elder), America's foremost expert on Russia, who had urged sending an expedition to eastern Siberia to help patriotic Russians "throw off the Bolshevik yoke and to set up an independent, anti-Bolshevik and anti-German government of their own" ${ }^{\prime 4}$.

While Engelstein highlights how General William Graves, commander of the U. S. expedition to Siberia, resisted State Department pressure to support Admiral Alexander Kolchak's armies more directly, she makes no mention of Graves's counterpart in northern Russia, who allowed US soldiers to be sent two hundred miles south from Archangel, where they engaged in fierce fighting against Red forces from September 1918 to the spring of 1919. In fact, she does not even acknowledge that roughly five thousand U.S. troops were sent to Archangel ${ }^{45}$.

Engelstein's treatment of US intervention in the Russian civil war is unbalanced and unconvincing. It is unfortunate that such a distinguished historian did not read widely enough to produce a more satisfactory account of an important and controversial episode in the history of American-Russian relations.

\section{Conclusion: Beyond Ideological History}

Both McMeekin and Engelstein present their works as efforts to move beyond distorting ideology. McMeekin claims to provide a dispassionate post-Cold War perspective, freed from "ideological argument" and based on "the solid ground of fact" 46 . More subtly, Engelstein introduces her book as a story "told with some degree of detachment from the ideological arguments that animated the revolution in the first place" 47 .

However, non-Marxist history is not necessarily or inherently non-ideological history. McMeekin's epilogue, titled "The Specter of Communism", makes it clear that his perspective on the Russian revolutions is strongly affected by conservative assumptions, fears, and injunctions: that "social inequality will always be with us", that "Marxist-style maximalist socialism is on the rise again", and that it is necessary to "resist armed prophets promising social perfection"48.

In contrast to McMeekin's neo-monarchist conservatism, Engelstein's interpretation is shaped by liberal democratic ideology. That becomes most obvious when she warns in both her introduction and conclusion that in 2017, as in 1917, the dream of democracy is threatened by "demagogues and hate-mongers". Yet her attachment to liberalism is evi-

${ }^{44}$ Foglesong D. S. America’s Secret... P. 88, 162, 202-204, 163.

45 Engelstein mentions British, but not US, troops in Arkhangelsk: Engelstein L. Russia in Flames... P. 305-306, 399. On the US role in northern Russia, see: Rhodes B.D. The Anglo-American Winter War with Russia. New York, 1988; Goldin V.I. Interventsiia i antibolshevistskoe dvizhenie na Russkom Severe, 1918-1920. Moscow, 1993.

${ }^{46}$ McMeekin S. The Russian Revolution: a New History... P. xiii.

${ }^{47}$ Engelstein L. Russia in Flames.... P. xxiii.

${ }^{48}$ McMeekin S. The Russian Revolution: a New History... P. 351-352. 
dent throughout her account, in which she sympathizes with and partially reproduces the views of Russian and American liberals from 1917-1918 ${ }^{49}$.

Historians who strive to write accounts of the Russian revolutions with enduring value must do more than McMeekin and Engelstein to set aside ideological commitments and preconceptions ${ }^{50}$. Crucial to such efforts will be resisting the temptation to view revolutionary Russia in a post-Soviet hindsight that naturalizes the supposed universal triumph of democratic capitalism in the late 1980s and early 1990s. Avoiding that temptation will enable scholars to be free not only from Marxist teleology but also from conservative and liberal convictions emboldened by the alleged "end of history" ${ }^{1}$. Some historians believe that the "fall of communism has altered everyone's perspectives on its birth" in a positive way, with the tearing down of the Berlin Wall underpinning "the best new writing" about the Russian revolutions ${ }^{52}$. Yet if the common belief that Western victory in the Cold War settled for all times fundamental questions about the merits of capitalism, democracy, socialism, and communism ${ }^{53}$ leads historians to write history with unquestioning faith in their own ideological convictions then the end of the Cold War will not be an unmixed blessing for scholarship.

\section{References}

Baumgart B. Deutsche Ostpolitik 1918. Vienna; Munich, Oldenbourg Publ., 1966, 462 S.

Davis D., Trani E. P. The First Cold War: the Legacy of Woodrow Wilson in U. S.-Soviet Relations. Columbia, University of Missouri Press, 2002, 329 p.

Engelstein L. Russia in Flames: War, Revolution, Civil War, 1914-1921. New York, Oxford University Press, 2017, 823 p.

Figes O. A People's Tragedy: a History of the Russian Revolution. New York, Viking Publ., 1996, 923 p.

Foglesong D. S. America's Secret War Against Bolshevism: U. S. Intervention in the Russian Civil War, 19171920. Chapel Hill, University of North Carolina Press, 1995, 386 p.

Foglesong D.S. Foreign Intervention. Critical Companion to the Russian Revolution, 1914-1921. Ed. by E. Acton. London, Arnold Publ., 1997, pp. 106-114.

Gaddis J. The Cold War: a New History. New York, Penguin Publ., 2005, 333 p.

Gaddis J. Russia, the Soviet Union, and the United States: An Interpretive History. ${ }^{\text {nd }}$ ed. New York, McGraw Hill Publ., 1990, 360 p.

Goldin V.I. Interventsiia i antibolshevistskoe dvizhenie na Russkom Severe, 1918-1920. Moscow, Moscow State University Press, 1993, 200 p. (In Russian)

Kennan G. F. Soviet-American Relations, 1917-1920. Vol. 1. New York, Norton Publ., 1956, 544 p.

Kennan G. F. Soviet-American Relations, 1917-1920. Vol.2, New York, Norton Publ., 1958, 513 p.

Kennan G.F. Soviet Historiography and America's Role in the Intervention. American Historical Review, 1960, vol. 65, no. 2, pp. 302-322.

Kennan G. F. The Fateful Alliance: France, Russia and the Coming of the First World War. New York, Pantheon Publ., 1984, 400 p.

Kennan G. F. The Sisson Documents. Journal of Modern History, 1956, vol. 28, no. 2, pp. 130-154.

Lasch C. American Intervention in Siberia: a Reinterpretation. Political Science Quarterly, 1962, vol.77, no. 2, pp. 205-223.

${ }^{49}$ Engelstein L. Russia in Flames... P. xxiii, 637.

50 British historian S. A. Smith is more successful in avoiding moralizing and writing dispassionately in Russia in Revolution: Smith S. A. An Empire in Crisis, 1890 to 1928. Oxford, 2017.

51 Fukuyama F. The End of History // The National Interest. 1989. June. For further discussion of the problem of hindsight, see: Fitzpatrick S. What's Left? // London Review of Books. 2017. Vol.39. N.10. Pp. 13-15.

${ }_{52}$ Merridale C. The Russian Revolution by Sean McMeekin — out of the blue // Financial Times. 2017. June 2.

53 Gaddis J.L. The Cold War: A New History. New York, 2005. 
Levin N. G. Woodrow Wilson and World Politics. New York, Oxford University Press, 1968, 340 p.

McMeekin S. The Russian Origins of the First World War. Cambridge (MA), Harvard University Press, 2011, $324 \mathrm{p}$.

McMeekin S. The Russian Revolution: a New History. New York, Basic Books Publ., 2017, 480 p.

Richard C. When the United States Invaded Russia: Woodrow Wilson's Siberian Disaster. Lanham (MD), Rowman and Littlefield Publ., 2013, 195 p.

Rhodes B. The Anglo-American Winter War with Russia. New York, Greenwood Press, 1988, 156 p.

Smith S. A. Russia in Revolution: an Empire in Crisis, 1890 to 1928. Oxford, Oxford University Press, 2017, $472 \mathrm{p}$.

Steinberg M.D. The Russian Revolution, 1905-1921. New York, Oxford University Press, 2017, 308 p.

Unterberger B. America's Siberian Expedition, 1918-1920. Durham (NC), Duke University Press, 1956, $271 \mathrm{p}$.

Unterberger B. Intervention Against Communism: Did the United States Try to Overthrow the Soviet Government, 1918-1920? College Station, Texas, Texas A\&M University Press, 1987.

Unterberger B. Woodrow Wilson and the Russian Revolution. Woodrow Wilson and a Revolutionary World. Ed. by A. Link. Chapel Hill, University of North Carolina Press, 1982, pp. 71-90.

Wildman A.K. The End of the Russian Imperial Army: the Old Army and the Soldiers Revolt (March-April 1917). Vol. I. Princeton, Princeton University Press, 1980, 402 p.

Wildman A. K. The End of the Russian Imperial Army: the Road to Soviet Power and Peace. Vol. II. Princeton, Princeton University Press, 1987, 443 p.

Willett R. Russian Sideshow: America's Undeclared War, 1918-1920. Washington (DC), Brassey's Publ., 2003, $327 \mathrm{p}$.

Williams W.A. American Intervention in Russia, 1917-1920. Studies on the Left, 1963, vol.3, no.4, pp. 24-48.

Williams W.A. American Intervention in Russia, 1917-1920. Studies on the Left, 1964, vol.4, no.1, pp.39-57.

Received: 16.01 .2018

Accepted: 31.05 .2018 